\title{
Evaluation of Cephalic Indices: A Clue for Racial and Sex Diversity
}

\author{
Evaluación del Índice Cefálico: Una Clave de la Diversidad Racial y de Sexo
}

\author{
Isurani Ilayperuma
}

\begin{abstract}
ILAYPERUMA, I. Evaluation of cephalic indices: a clue for racial and sex diversity. Int. J. Morphol., 29(1):112-117, 2011.
SUMMARY: Cephalic index is an important parameter in evaluating racial and gender differences. A large body of evidence shows a clear racial variation in cephalic index. Therefore detailed knowledge of the population specific data on biometric features of the cranium is important in the study and comparison of the crania of populations from different racial backgrounds, assessing growth and development of an individual and in the diagnosis of any abnormalities of cranial size and shape. Despite its' significance, little is known concerning the cranial morphometry in Sri Lankans. Hence, the present study was undertaken to establish the cranial indices and head shapes in an adult Sri Lankan population. A total of 400 subjects with an age span of 20-23 years were included in the study. The cranial length, breadth and auricular head height of the subjects were recorded using a digital sliding caliper and Todd's head spanner. The horizontal, vertical and transverse cephalic indices were calculated using external dimensions of the skulls. There were significant gender differences in all principal cranial dimensions. The mean horizontal, vertical and transverse cephalic indices were 78.54, 78.68 and 100.52 respectively. The predominant cephalic phenotype of the study subjects were brachycephalic, hypsicephalic and acrocephalic. Among males dolicocephalics and among females brachycephalics dominated. The results of this study highlight the racial and gender differences in cranial morphometry and cephalic indices in an adult Sri Lankan population. The data will be of immense use in clinical, medico-legal, anthropological and archeological scenarios.
\end{abstract}

KEY WORDS: Cephalic indices; Sex; Racial diversity; Sri Lanka.

\section{INTRODUCTION}

Variety of non-metric and metric parameters has been utilized in the assessment of ethnic and sex differences of the skull. The non-metric parameters are subjective as no quantitative techniques are devised. On the other hand, features that can be expressed as actual measurements, like cephalic indices provide a system for metrical recording of sizes and proportions of cranial features instead of subjective impressions (Williams et al., 2000). Since these indices yield a numerical expression, it is an important parameter in evaluating inter and intra population comparisons of crania as well as the sexual dimorphism (Shah \& Jadhav, 2004; Williams et al.). It also permits comparison of cranial morphometry between parents, offspring and siblings which may provide a clue to genetic transmission of inherited characters (Shah \& Jadhav). In addition, standardized cephalometric data enable diagnostic comparison between patients and the normal population (Rabey, 1971). It has been shown that doliocephalics are less prone to otitis media than the brachycephalics (Stolovitsky \& Todd, 1990). Furthermore it is reported that individuals with Apert's syndrome are hyperbrachycephalic (Cohen \& Kreiborg, 1994).

Evidence shows a clear racial trend in the cranial dimensions and cephalic indices among different populations such as, Caucasians, Indians, Turkman and native Fars groups, Kosov and Albanians, Iranians, Japanese, Serbs, Greek, Bulgarians, Mapuche individuals in Chile, Nigerians, Caucasians (Abolhasanzadeh \& Farahani, 2003; Rexhepi \& Meka, 2008; Kasai et al., 1993; Obikili \& Singh, 1992; del Sol, 2005; Okupe et al., 1984).

Furthermore, racial variation in cephalic index is clearly demonstrated by comparative studies between Nigerians and Caucasians, where Nigerians were shown to have a significantly higher cephalic index than the Caucasians (Okupe et al.). 
Taken together, knowledge on the cranial morphometry is important in the study and comparison of the crania of populations from different racial, geographic and dietary backgrounds. Such information is also useful in studies of primate phylogeny. In clinical practice, population and age specific data on cephalic indices give an indication of growth and development of an individual and also any abnormalities of cranial size and shape (Harper et al., 1984).

Despite its significance and practical use little is known concerning the cephalic index and prevalence of cephalic phenotypes in Sri Lankans, inhabitants of the South Asian country. Hence, this study was designed to elucidate the norms for cephalic indices and the types of head shapes.

\section{MATERIAL AND METHOD}

This study was conducted on 400 medical students (220 male and 180 female) of the Faculty of Medicine, University of Ruhuna, Galle, Sri Lanka. The subjects were apparently healthy and without any craniofacial deformity. They were from different parts of the island belonging to different socio-economic status. The age of the subjects ranged from 20-23 years.

The following external linear dimensions of the skulls were recorded (Williams et al.):

1. Maximum cranial length (glabella-inion length). It is defined as the straight distance between the most prominent point on the frontal bone above the root of the nose (glabella) and the most prominent portion of the occipital bone. This was measured by placing the anterior caliper tip on the glabella while allowing the posterior caliper tip to slide inferiorly along the median plain of the occipital bone until the maximum length was reached.

2. Maximum cranial breadth (maximum biparietal diameter). It is defined as the maximum distance between the most lateral points of the parietal bones. This was measured by allowing both tips of the spreading caliper to slide down along the lateral aspects of the parietal bones until the maximum width was recorded.

Maximum antero-posterior cranial length and maximum cranial breadth were measured using a digital spreading caliper (Mitutoyo, Japan) capable of measuring to the nearest $0.01 \mathrm{~mm}$.

3. Maximum auricular head height. It is defined as the distance between the external acoustic meatus and the highest point of the vertex (bregma). The measurement was recorded on both sides using the Todd's head spanner.

The above measurements were recorded at a fixed time between 14:00 - 16:30 hours to eliminate discrepancies due to diurnal variation. All the measurements were repeated thrice and the mean was taken for further analysis. Furthermore, the measurements were recorded by the same person to minimize the errors in methodology. Results were expressed as mean \pm SD and analyzed using the Statistical Package for Social Sciences (SPSS), 15th version. A comparison of the mean values and proportions between sexes was performed using the t-test and Z-test respectively. $\mathrm{P}$ value $<0.05$ was considered statistically significant.

The following cranial indices were calculated using the above measurements (Martin \& Saller, 1957; Rexhepi \& Meka):

Horizontal cephalic index $(\mathrm{HCI})=$ Maximum cranial breadth/ Maximum cranial length x 100\%.

Vertical cephalic index $(\mathrm{VCI})=$ Maximum auricular head height/ Maximum cranial length x 100\%.

Transverse cephalic index $(\mathrm{TCI})=$ Maximum auricular head height/ Maximum cranial breadth x 100\%.

Craniotyping were based on the ranges in horizontal, vertical and transverse cephalic indices as follows (Martin \& Saller; Rexhepi \& Meka):

According to the horizontal cephalic index head shapes were classified as dolichocephalic $(71.0<\mathrm{HCI}>$ 75.9), mesocephalic $(76.0<\mathrm{HCI}>80.9)$, brachycephalic $(81.0<\mathrm{HCI}>85.90)$ and hyperbrachycephalic $(86.0<\mathrm{HCI})$;

According to the vertical cephalic index head shapes were classified as chamaecephalic $(57.9>\mathrm{VCI})$, orthocephalic $(58.0<\mathrm{VCI}>62.9)$ and hypsicephalic $(63<\mathrm{VCI})$;

According to the transverse cephalic index head shapes were classified as tapeiocephalic $(78.9>\mathrm{VCI})$, metriocephalic $79.0<\mathrm{TCI}>84.9)$ and acrocephalic $(85.0<\mathrm{TCI})$.

\section{RESULTS}

The mean ages of the study subjects (male: $21.03 \pm$ 0.88 ; female $21.27 \pm 0.89$ ) were not significantly different between sexes (Table I). Gender differences with respect to the mean cranial length, cranial breadth and auricular head 
height were found to be significantly larger in males compared to females $(\mathrm{P}<0.001)$ (Table I). The mean horizontal, vertical and transverse cephalic indices in males and females were found to be 78.04, 78.53, 101.12 and 79.32, 78.91, 99.61 respectively (Table I). Thus, Sri Lankan males have a significantly higher horizontal and transverse cephalic indices than females $(\mathrm{p}<0.001)$. However, there was no significant sex difference in vertical cephalic index.

The morphological classification of the head was carried out according to the horizontal, vertical and transverse cephalic indices. The dominant type of cephalic phenotype according to the horizontal cephalic index was brachycephalic with a frequency of $66.15 \%$ which was followed by dolichocephalic (58.07\%) and mesocephalic types (53.07\%). The rare type was the hyperbrachycephalic $(22.69 \%)$. However, among males dolicocephalics and among females brachycephalics predominated (Table II, Fig. 1).

Cephalic phenotyping according to the vertical cephalic index showed that the large majority of the study subjects (96.06 \%) belong to hypsicephalic category irrespective of the sex. Among the females $(7.69 \%)$ and none among the males were orthocephalics (Table III; Fig. 2).

According to the categorization of transverse cephalic

Table I. Cranial dimensions and cephalic indices of the study subjects.

\begin{tabular}{lccc}
\hline Parameter & Male & Female & Both Sexes \\
\hline Cranial length & $180.5 \pm 13.22^{*}$ & $175 \pm 6.61$ & $177.89 \pm 10.71$ \\
Cranial breadth & $147.80 \pm 5.53^{*}$ & $141.11 \pm 7.41$ & $144.63 \pm 7.17$ \\
Auricular head height & $140.20 \pm 10.35^{*}$ & $138.89 \pm 12.94$ & $139.58 \pm 11.33$ \\
HCI & $78.04 \pm 6.53^{*}$ & $79.32 \pm 6.25$ & $78.54 \pm 6.35$ \\
VCI & $78.53 \pm 4.91$ & $78.91 \pm 7.46$ & $78.68 \pm 5.93$ \\
TCI & $101.12 \pm 8.57^{*}$ & $99.61 \pm 7.29$ & $100.52 \pm 8.01$ \\
\hline
\end{tabular}

$* \mathrm{P}<0.05$.

Table II. Frequencies of the categories of head types according to horizontal cephalic index.

\begin{tabular}{lccc}
\hline Head shape & Male & Female & Both sexes \\
\hline Dolichocephalic & $35^{*}$ & 23.07 & 58.07 \\
Mesocephalic & 30 & 23.07 & 53.07 \\
Brachycephalic & $20^{*}$ & 46.15 & 66.15 \\
Hyperbrachyceph & 15 & 7.69 & 22.69 \\
\hline
\end{tabular}

$* \mathrm{P}<0.05$.

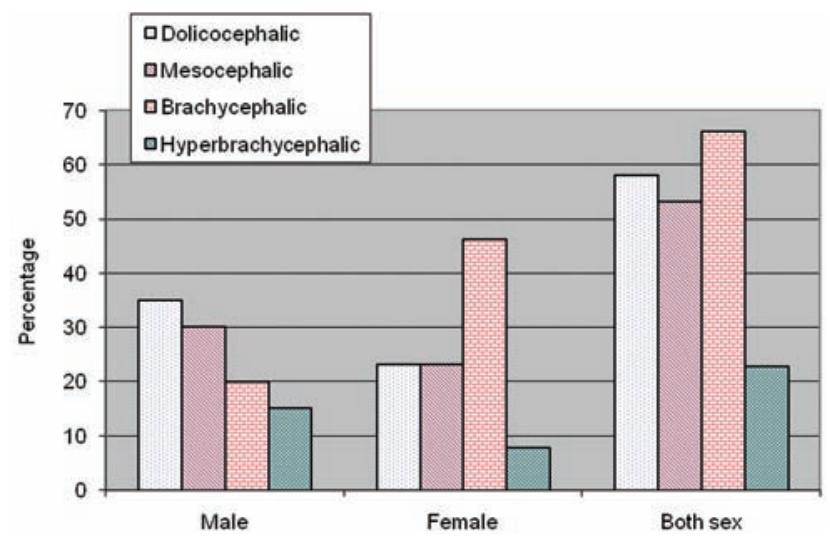

Fig.1. Frequency of head types according to horizontal cephalic index.
Table III. Frequencies of the categories of head types according to vertical cephalic index.

\begin{tabular}{lccc}
\hline Head shape & Male & Female & Both sexes \\
\hline Hypsicephalic & $100^{*}$ & 92.31 & 96.06 \\
Orthocephalic & $0^{*}$ & 7.69 & 3.03 \\
Chamaecephalic & 0 & 0 & 0 \\
\hline
\end{tabular}

$* \mathrm{P}<0.05$.

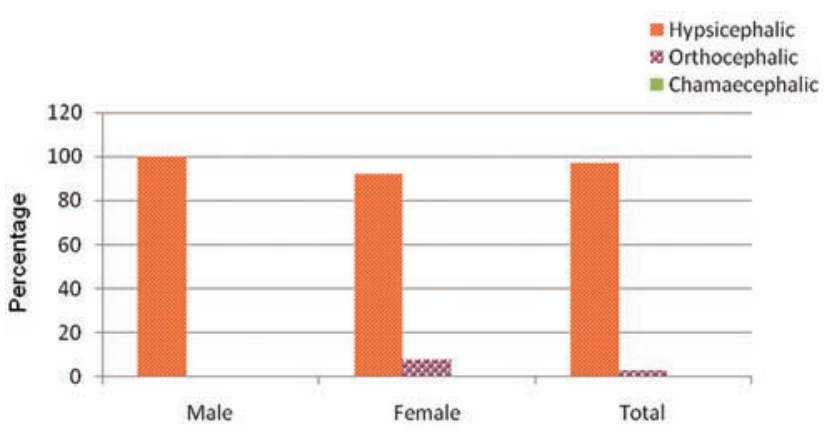

Fig. 2. Frequency of head types according to vertical cephalic index. 
index, the most dominant head type was acrocephalics (93.94\%) which was followed by metriocephalics to a lesser

Table IV. Frequencies of the categories of head types according to transverse cephalic index.

\begin{tabular}{lccc}
\hline Head shape & Male & Female & Both sex \\
\hline Metriocephalic & 5 & 7.69 & 6.06 \\
Acrocephalic & 95 & 92.31 & 93.94 \\
Tapeinocephalic & 0 & 0 & 0 \\
\hline
\end{tabular}

\section{DISCUSSION}

The present study provides valuable new data pertaining to the cephalic indices and shapes of the heads in an adult Sri Lankan population. It is stated that the racial characters are best defined in the skull (Oladipo et al., 2009; William et al.). As a result cranial morphometry, and hence the cephalic indices constitute the most important characters for determining the racial difference (William et al.).

Diverse craniometric approaches have been proposed and utilized to estimate the cranial capacity either on dry skulls or living subjects (William et al.). Over the course of this study cephalic indices were estimated based on the linear dimensions of the skulls. The cephalometry provides a reliable, relatively easy and quick method. Furthermore, this approach has the added advantage as it does not require any sophisticated techniques. Taken together, cephalometry continues to be the most versatile technique in the investigations of the craniofacial skeleton (McIntyre \& Mossey, 2003; Vojdani et al., 2009).

The mean horizontal cephalic index observed in this study (78.54) was lower than those observed for the Turkman: 80.4 (Golalipour et al., 2007), Indians: 80.42 (Shah \& Jadhav), Mapuche individuals in Chile: 80.42 (del Sol), native Fars: 84.8 (Golalipour, 2006), European people in Mediterranean area: 81.19, North Europeans: 79.72 (Garcia \& Lips, 1986a, b), Japanese: 87 (Nakashima, 1986) and higher than in Iranians: 75 (Abolhasanzadeh \& Farahani), a finding that further reinforces the racial diversity in the cephalic index.

The most common head shape in the present study was brachycephalic $(66.15 \%)$, which was in agreement with the Turkmans: $42.4 \%$ (Golalipour et al.) and Iranians: $36.6 \%$ (Abolhasanzadeh \& Farahani). Albanian Kosov populations: $50.4 \%$, Albanians: $79.5 \%$ and Greeks: $48.97 \%$ (Rexhepi \& Meka). However, dolicocepahalics predominated among Indians: 58.5\% (Bhatia et al., 1955), Bulgarians: $34 \%$ and Serbs: $39.2 \%$ (Rexhepi \& Meka). Mesocephalics predominated among Mapuche individuals: $66 \%$ (del Sol) degree (6.06\%). Tapeiocephalics were completely absent among the study population (Table IV, Fig. 3).

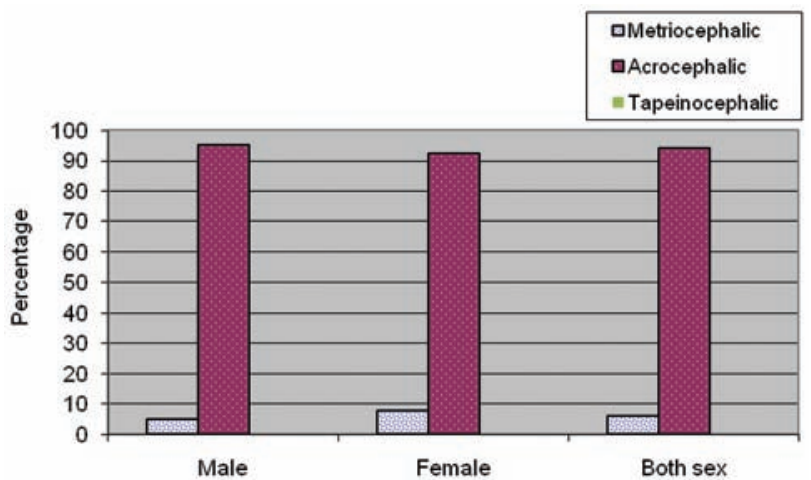

Fig. 3. Frequency of head types according to transverse cephalic index.

and Gujaratees in India: $41 \%$ (Shah \& Jadhav). Among native Fars the majority were hyperbrachycephalic: $52 \%$ (Golalipour) beautifully highlighting the racial diversity in cranial morphology.

Variations in cephalic indices between and within populations have been attributed to a complex interaction of genetic and environmental factors (Kasai et al.; Okupe et al.; Golalipour). The mean cephalic indices within different Indian groups were shown a range from 79.50 to 80.81 (Sha \& Jadhav). In addition, the cephalic phenotypes among these groups were shown to vary from predominantly mesocephalic to brachycephalic (Sha \& Jardev). Anthropometric comparison of cephalic indices between the Itsekiris and Urhobo ethnic groups in Nigeria showed mean cephalic indices of 82.16 and 86.80 respectively (Oladipo \& Paul, 2009).

Cranial dimensions have been shown to depend on gene expression (Okupe et al.) and since gene expression differs in various racial and ethnic groups it becomes a determining factor. It was shown that the first generation of Japanese immigrants in Hawaii had a higher cephalic index than their parents (Heravi \& Zieaee, 2002). It was interesting to note that cephalic index varies significantly among populations in different geographical zones (Bharati et al., 2001).

The cephalic indices and head shapes presented in this study are valid for the age group (20-23 years) of the study population. It has been clearly stated that cranial dimensions varies with the age of an individual reaching its peak around 16-20 years of life (Kondo et al., 1999; Knutson et al., 2001). Age can also induce the gradual expression of genetic characteristics in individuals. A group of black Africans tends to become more dolicocephalic than their white peers within the first two years of life (Okanlawon et al., 1990). In addition, it has been observed that a natural decrease in the cephalic 
index occurs within the first three years of life (Krásnicanová, 1990). Furthermore, in the interpretation of skull radiographs there is often a need for baseline set of data for standard skull size, especially where the possibility of cerebral atrophy or mild hydrocephalus or abnormality in the shape of the skull is in question.

Furthermore, it was also shown that changes occur in the head form and shape of subsequent generations of a specific population over a long period of time (Nakashima; Vojdani et $a l$.$) . Interestingly, even dietary habits have been shown to$ influence the craniofacial form of a population (Kasai et al.). Brachycephalization is thought to be due to relative higher increase in the head breadth in comparison with the head length as a result of improvement in nutrition (Kouchi, 2000).

It is widely known that sexual dimorphism is an important component of the morphological variation in biological populations (Williams et al.). The gender differences in cranial morphology emphasize the significance of applying the anatomical variation data to an individual subject in a given population. It is also important to note that, the rates of skeletal maturity in males and females vary during the course of growth and development (Williams et al.).

The significance of gender, age and population specific craniometric data is of multifold. Firstly, comparison of the cephalic indices and head shapes with the standards for the same age, race, and sex is a valuable tool for diagnosis, treatment monitoring and prediction of orthodensy treatment results (Grau et al., 2001). Such knowledge will also have applicability in plastic and oral surgery concerned with craniofacial deformity (Williams et al.). Secondly, it provides important evidence in forensics cranio-facial reconstruction and in attempts to reconstruct appearances of cranium in life of individuals represented only by cranial remains in anthropological studies. Taken together the evidence suggests that the value of population, gender and age specific data on cephalic indices cannot be underestimated.

ILAYPERUMA, I. Evaluación de los índices cefálicos: una clave de la diversidad racial y de sexo. Int. J. Morphol., 29(1):112-117, 2011 .

RESUMEN: El índice cefálico es un parámetro importante para evaluar las diferencias raciales y sexuales. Una gran cantidad de evidencia muestra una clara variación racial en el índice cefálico. Por tanto, un conocimiento detallado de los datos específicos de una población sobre las características biométricas del cráneo, son importantes en el estudio y la comparación craneal de poblaciones de diferentes orígenes raciales, evaluación del crecimiento y desarrollo de un individuo, y el diagnóstico de cualquier anomalía del tamaño o forma del cráneo. A pesar de su importancia, poco se conoce sobre la morfometría craneal en Sri Lanka. El presente estudio se realizó para establecer los índices cefálicos y formas de la cabeza en una población adulta de Sri Lanka. Un total de 400 sujetos entre 20 y 23 años fueron incluidos en el estudio. La longitud de la cabeza, ancho y altura auricular fueron registradas con un caliper digital deslizante y un aparato de Todd. Los índices cefálicos horizontales, verticales y transversales fueron calculados utilizando las dimensiones externas de los cráneos. Hubo diferencias significativas de sexo en todas las dimensiones de la cabeza. La media horizontal, vertical y transversal de los índices cefálicos fueron 78,54; 78,68 y 100,52, respectivamente. Los fenotipos cefálicos predominantes fueron braquicéfalos, hipsicefálicos y acrocéfalos. Entre los hombres dominaron los dolicocefalos y entre mujeres los braquicéfalos. Los resultados de este estudio ponen de relieve la diversidad racial y las diferencias de sexo en la morfometría craneal e índice cefálico en una población adulta de Sri Lanka. La información será de utilidad inmensa en clínica, medicina legal, escenarios antropológicos y arqueológicos.

PALABRAS CLAVE: Índices cefálicos; Sexo; Diversidad racial; Sri Lanka.

\section{REFERENCES}

Abolhasanzadeh, A. \& Farahani, M. R. Standarded international classification of head shapes of 22-24 years old in Tehran. J. of Research in Medicine, 26:281-5, 2003.

Bharati, S.; Som, S.; Bharati, P. \& Vasulu, T. S. Climate and head form in India. Am. J. Hum. Biol., 13:626-34, 2001.

Bhatia, M.; Thin, J.; Debray, H. \& Cabanes, J. Étude anthropologique et genetique de la population du nord de
l'Inde. Bull Et Mem. Soc. d'Anthrop. de Paris, 10: 199$213,1955$.

Cohen, M. M. \& Kreiborg, S. Cranial size and configuration in the Apert's Syndrome. J. Craniofac. Genec. Dev. Biol., 14:95-102, 1994.

Del Sol, M. Cephalic index in a group of Mapuche individuals in the IX region of Chile. Int. J. Morphol., 23:241-6, 2005. 
García, H. F. \& Lips, M. W. Contribución al estudio del índice cefálico en chilenos. An. Anat. Norm., 4:120-3, 1986a.

García, H. F. \& Lips, M. W. Variaciones del índice cefálico chilenos segun ascendencia. An. Anat. Norm., 4:117-9, 1986b.

Golalipour, M. J.; Jahanshahi, M. \& Haidari, K. Morphological evaluation of head in Turkman males in Gorgan-North of Iran. Int. J. Morphol., 25: 99-102, 2007.

Golalipour, M. J. The variation of head shapes in 17-20 years old native Fars male in Gorgan-North of Iran. Int. J. Morphol., 24:187-90, 2006.

Grau, V.; Alcañiz, M.; Juan, M. C.; Monserrat, C. \& Knoll, C. Automatic localization of cephalometric landmarks. $J$. Biomed Inform., 34:146-56, 2001.

Harper, C.; Krill, J.; Raven, D. \& Jones, N. Intracranial cavity volumes: a new method and its potential applications. Neuropathol. Appl. Neurobiol., 10:25-32, 1984.

Heravi, F. \& Zieaee, H. Assessing the importance of cephalic and facial indices in a group of 12 years old boys in Mashhad. Beheshti Univ. Dent. J., 20:119-24, 2002.

Kasai, K.; Richards, T. C. \& Brown, T. Comparative study of craniofacial morphology in Japanese and Australian aboriginal populations. Hum. Biol., 65:821-34, 1993.

Knutson, B.; Momenan, R.; Rawlings, R. R.; Fong, G. W. \& Hommer, D. Negative association of neuroticism with brain volume ratio in healthy humans. Biol. Psychiatry, 50:685$90 ; 2001$.

Kondo, S; Wakatsuki, E. \& Shibagaki, H. A. Somatometric study of the head and face in Japanese adolescents. Okajimas Folia Anat. Jpn., 76:179-85, 1999.

Kouchi, M. Brachycephalization in Japan has ceased. Am. J. Phys. Anthropol., 112:339-47, 2000.

Krásnicanová, H. Clinical and anthropologic aspects of form and size of the child's head. Arztl. Jugendkd., 81:327-30, 1990.

Martin, R. \& Saller, K. Lehrbuch der anthropologie. Stuttgart, Gustav Fischer Verlag, 1957.

McIntyre, G. T. \& Mossey, P. A. Size and shape measurement in contemporary cephaometrics. Eur. J. Orthod., 25:231-42, 2003.

Nakashima, T. Brachycephalization in the head form of school girls in North Kyushu. J UOEH., 8:411-4, 1986.
Obikili, E. N. \& Singh, S. P. Secular growth trend in the adult stature of Nigerians. Orient J. Med., 4:44-7, 1992.

Okanlawon, A. O.; Ejiwunmi, A. B.; Rosanwo, M. O. \& Ojo, O. O. Standards of craniofacial dimension for an African population. East Afr. Med. J., 67:254-9, 1990.

Okupe, R. F.; Coker, O. O. \& Gbajumo, S. A. Assessment of biparietal diameter during normal pregnancy in Nigerian women. Br. J. Obstet. Gynaecol., 99:629-632, 1984.

Oladipo, G. S. \& Paul, C. W. Anthropometric comparison of cephalic indices between the Urhobo and Itsekiri ethnic group of Nigeria. Global J. Pure Appl. Sci., 15:65-7, 2009.

Oladipo, G. S.; Olotu, J. E. \& Suleiman, Y. Anthropometric studies of cephalic indices of the Ogonis in Nigeria. Asian J. Med. Sci., 1:15-7, 2009.

Rabey, G. P. Craniofacial morphanalysis. Proc. R. Soc. Med., 64:103-11, 1971.

Rexhepi, A. \& Meka, V. Cephalofacial morphological characteristics of Albanian Kosova population. Int. J. Morphol., 26:935-40, 2008.

Shah, G. V. \& Jadhav, H. R. The study of cephalic index in students of Gujarat. J. Anat. Soc. India, 53:25-26, 2004.

Stolovitsky, J. P. \& Todd, N. W. Head shape and abnormal appearance of tympanic membranes. Otolaryngol. Head, Neck Surg., 102:322-5, 1990.

Vojdani, Z.; Bahmanpour, S.; Momeni, S.; Vasaghi, A.; Yazdizadeh, A.; Karamifar, A.; Najafifar, A.; Setoodehmaram, S. \& Mokhtar, A. Cephalometry in 14-18 years old girls and boys of Shiraz-Iran high school. Int. J. Morphol., 27:101-4, 2009.

Williams, P. L.; Bannister, L. H.; Berry, M. M.; Collins, P.; Dyson, M.; Dussek, J. E. Gray's Anatomy: The anatomical basis of medicine and surgery. $38^{\text {th }}$ Ed. New York, Churchill Livingstone, 2000.

\section{Correspondence to:}

Dr. Isurani llayperuma, Ph.D.

Department of Anatomy

Faculty of Medicine

University of Ruhuna

P.O.Box 70, Galle

SRI LANKA

Telephone: 0094-91-2234801

Fax: 0094-91-2222314

E-mail: iisurani@yahoo.com

Received: 06-07-2010 Accepted: 19-12-2010 